\title{
DO ATIVISMO AO PROTAGONISMO JUDICAL: POR UMA ATUAÇÃO TRANSFORMADORA NA SEARA AMBIENTAL
}

\author{
FROM JUDICIAL ACTIVISM TO JUDICIAL PROTAGONISM: FOR A \\ TRANSFORMING ACTUATION IN THE ENVIRONMENTAL SUBJECT
}

\begin{abstract}
${ }^{1}$ Iasna Chaves Viana ${ }^{2}$ Emilio de Medeiros Viana

\section{RESUMO}

O ambiente de atuação do julgador transformou-se em ágora moderna, espaço preferencial das deliberações públicas mais relevantes. Há hoje uma invasão dos espaços habituais de escolhas públicas pela judicialização da política, resultado do desenho institucional brasileiro. Os conceitos de ativismo e protagonismo judicial se contrapõem nesse cenário. Na atualidade impõe-se atuação judicial protagonista, transformadora da realidade, assim entendida aquela que se volta para emprestar máxima efetividade ao Texto Constitucional. Especialmente relevante quando se trata da temática ambiental, diante da enorme complexidade da sociedade atual. Estudo de casos busca evidenciar a evolução do entendimento do Judiciário brasileiro a tal respeito.
\end{abstract}

Palavras-chave: Protagonismo Judicial. Ativismo Judicial. Judicialização da Política. Meio Ambiente.

\begin{abstract}
The judge's action setting became modern ágora, preferential space of the relevant public deliberations. Today there is an invasion of the public choices' usual spaces by the legalization of politics, result of Brazil's institutional design. The concepts of judicial activism and judicial protagonism oppose this scenario. At present it must be judicial action protagonist, transforming reality, understood that which is back to lend maximum effect to the Constitutional text. Especially relevant when it comes to environmental issues, given the enormous complexity of today's society. Case studies aim to show the evolution of the Brazilian Judicial understanding in this regard.
\end{abstract}

Keywords: Judicial Protagonism. Judicial Activism. Judicialization of Politics. Environment.

\footnotetext{
${ }^{1}$ Mestranda em Direito Privado pelo Centro Universitário 7 de Setembro - Uni7, Ceará (Brasil). Membro do Grupo de Pesquisa em Tributação Ambiental da Faculdade de Direito da Universidade Federal do Ceará - UFC, Ceará (Brasil). E-mail: iasnaviana@yahoo.com.br

${ }^{2}$ Doutorando em Direito Constitucional pela Universidade de Fortaleza - UNIFOR, Ceará (Brasil). Professor do Centro Universitário 7 de Setembro - Uni7, Ceará (Brasil). Juiz de Direito no Ceará. E-mail: emilio.viana71@gmail.com
} 


\section{INTRODUÇÃO}

O início do século XXI aponta para modelo de Estado em que predomina a atividade judicial. A jurisdição avança progressivamente sobre os espaços de deliberações públicas, antes reservados aos poderes políticos majoritários (Legislativo e Executivo).

Em tal contexto, avulta na vida nacional o papel do Poder Judiciário - especialmente o do Supremo Tribunal Federal (STF). Por causas diversas, as mais relevantes decisões para a sociedade brasileira passam, a cada dia, pela arena judicial. $\mathrm{O}$ ambiente de atuação do julgador transforma-se em ágora moderna, espaço preferencial das deliberações públicas mais relevantes. O processo já não é apenas instrumento de solução dos conflitos intersubjetivos. Eloquente a virada conceitual: a vocação do tempo presente já não é para a legislação e a ciência do Direito, mas para a jurisdição. O processo transmuda-se em autêntico instrumento de participação democrática.

A conjugação do modelo de constitucionalismo social com o reconhecimento do caráter normativo e judicialmente sindicável dos preceitos constitucionais - inclusive os mais vagos - alterou substancialmente a relevância da Constituição no sistema jurídico. Em decorrência, houve alteração no equilíbrio de poder estatal, com o fortalecimento do Judiciário e, sobretudo, das Cortes Constitucionais, não raras vezes em detrimento das escolhas realizadas nas instâncias políticas majoritárias (SOUZA NETO e SARMENTO, 2015, p. 76).

A expansão do poder judicial desafia críticas severas. As mais recorrentes dizem com o déficit de democracia de que padeceria a magistratura, formada por quem não se submeteu ao voto popular e que, mesmo assim, realiza revisão e reconstrução do sentido das deliberações dos que foram eleitos. Relevante anotar que o empoderamento do aparelho judicial também guarda relação com a técnica redacional cada vez mais utilizada em textos normativos constitucionais e infraconstitucionais. Conceitos vagos com os de função social da propriedade, desenvolvimento sustentável, livre concorrência, boa-fé objetiva, eficiência, duração razoável do processo, dentre outros, são densificados no momento da interpretação e aplicação pelo julgador. O ambiente decisional, em tais circunstâncias, é frouxo, permitindo utilização de elevado grau de criatividade pelo intérprete.

A liberdade decisional, lastreada em equivocada interpretação do princípio do livre convencimento motivado, ensejou decisões díspares, com pouca ou nenhuma preocupação com a estabilidade, a previsibilidade e a coerência do sistema. A prodigalidade de decisionismos de 
toda ordem contribuiu para autêntica loteria judicial. ${ }^{3}$ A questão ganha relevo maior quando observadas decisões relacionadas com escolhas públicas - como, por exemplo, aquelas que dizem com o controle judicial de políticas públicas e direitos fundamentais prestacionais. A intervenção judicial desmedida e a ausência de coerência e de critérios objetivos de atuação rompem a possibilidade de adequado planejamento e funcionamento da máquina pública.

Note-se, em outra toada, que a sociedade contemporânea vive em enorme complexidade social, com indiscutível repercussão nas questões que envolvem a proteção ao meio ambiente. A multiplicidade de riscos, os conflitos e demandas que daí resultam não são passíveis de soluções simples, resultantes de mera aplicação de normas constitucionais, legais e/ou regulamentares, por processo de subsunção. Diante disto, o trabalho desenvolvido visa enfrentar o seguinte problema: limites da atuação judicial, notadamente em questões que envolvem a proteção ao meio ambiente. A pesquisa é bibliográfica, descritiva, exploratória e jurisprudencial.

O trabalho foi dividido em quatro tópicos. Nos dois primeiros, é analisado o papel social do julgador na sociedade atual (de risco), contrapondo as noções de protagonismo e de ativismo judicial. No terceiro, são expostos institutos relacionados com a adequada compreensão de meio ambiente, em suas diferentes dimensões. No último, é realizado estudo de casos, tendo por referência demandas judiciais que envolveram a proteção ao meio ambiente. Foram selecionados, por amostragem, decisões do STF e decisão de Tribunal Regional Federal que envolveu a construção da sede da Procuradoria Regional da República (órgão constitucionalmente incumbido da proteção do meio ambiente). A partir dele, buscou-se aferir se, nos casos examinados, a atuação judicial correspondeu às expectativas constitucionalmente delineadas.

\section{A EXPANSÃO DO ESPAÇO DE ATUAÇÃO DA JURISDIÇÃO: A JUDICIALIZAÇÃO DA POLÍTICA}

A vocação do tempo presente é para a jurisdição. A passagem do Estado Liberal Clássico ao Estado Social de Direito, com a positivação dos direitos fundamentais nos textos constitucionais e o reconhecimento da força normativa dos mesmos - e, portanto, da pronta exigibilidade de tais direitos - ensejou incremento do poder dos juízes, originando o fenômeno

\footnotetext{
${ }^{3}$ A falta de coerência nas decisões judiciais acaba estimulando a prodigalização de demandas; cada um arrisca a possibilidade de uma decisão favorável.
} 
que se convencionou designar de judicialização da política (ou politização da justiça). Deliberações/tarefas antes atribuídas a outros órgãos são assumidas, por assim dizer, pelo Poder Judiciário.

Relevante anotar que prevalecia no cenário mundial, até bem pouco tempo, a visão segundo a qual a Constituição não representava mais que proclamação política, capaz de inspirar o Poder Legislativo. A maioria dos países não contava, até a segunda metade do século $\mathrm{XX}$, com mecanismos de controle judicial da constitucionalidade das leis. E mesmo onde havia previsão formal de tal controle, como no Brasil, o mesmo não desempenhava papel importante na cena política e/ou na rotina dos tribunais (SOUZA NETO e SARMENTO, 2015, p. 75). O cenário alterou-se desde o fim da $2^{\mathrm{a}}$ Guerra Mundial. O modelo de constitucionalismo norteamericano tornou-se hegemônico, com prodigalização da possibilidade de controle da constitucionalidade das leis e dos atos normativos. A Constituição passou a ser reconhecida como autêntica norma jurídica, com aptidão para gerar direitos ao cidadão e, portanto, com possibilidade de ser invocada na solução de casos concretos.

No cenário nacional, a Ordem Constitucional inaugurada em 1988, o extenso rol de direitos fundamentais então positivados e, de forma mais recente, a influência da Nova Hermenêutica Constitucional, das correntes neoconstitucionalistas e da moderna dogmática dos direitos fundamentais ${ }^{4}$ contribuíram sobremodo para crescente litigiosidade, notadamente com o fito de ver judicialmente efetivados tais direitos. A proliferação de demandas de aludida estirpe ensejou exageros que podem ser designados de ativismo judicial despreparado (SILVA, 2008, p. 571). Não raras vezes, referidos exageros espelham atuação judicial ideologicamente engajada.

Indiscutível que o Judiciário, pela sua capilaridade e pelas facilidades crescentes de acesso, é hoje o caminho mais seguro e eficaz para que os cidadãos, isoladamente ou por intermédio da sociedade organizada (associações), do Ministério Público ou da Defensoria Pública, busquem intervir diretamente na formação e no controle das vontades públicas.

Demasiadamente comum a afirmação de que ao Judiciário faleceria legitimidade democrática para imiscuir-se nas deliberações do Executivo e do Legislativo, uma vez que seus membros não se submetem ao controle popular pelo voto. Ao fazê-lo, intervindo na formação das vontades públicas e na execução das políticas públicas, o julgador estaria substituindo a vontade do povo, externada diretamente ou por meio de representantes democraticamente

\footnotetext{
${ }^{4}$ A propósito, veja-se Paulo Bonavides (BONAVIDES. 2007); Ana Paula de Barcellos (BARCELLOS, 2005); Ingo W. Sarlet (SARLET, 2009) e Virgílio Afonso da Silva (SILVA, 2009).
} 
eleitos, pela dele próprio. Haveria, em tais circunstâncias, insegurança e risco do estabelecimento de uma autêntica ditadura da toga, com a substituição das deliberações democráticas pelas deliberações judiciais.

A questão não desafia solução simples, impondo releitura do clássico dogma da separação de poderes, tudo de forma a compreender a moderna noção de que o Judiciário pode - e deve - atuar no sentido de ver efetivada a vontade constitucional, sendo tal atuação tida como meio de exercício de democracia deliberativa ${ }^{5}$, com participação franqueada a qualquer do povo para intervenção e controle na formação e execução das vontades públicas. Entender de forma diversa importaria em fazer letra morta do Texto Constitucional, sepultando as possibilidades de resgate das desigualdades sociais que sua promulgação buscou implementar.

Anotando a respeito do que ocorria na Europa continental, em passagem que, em tudo e por tudo, pode ser trasladada para a realidade nacional, Nicola Picardi (2008, p. 26) ressalta que, entre o século XVIII (berço das ideias iluministas e do advento da teoria da separação de poderes) e a primeira metade do século XX, registrou-se burocratização da função do juiz, com igualação substancial das funções judiciária e administrativa. Tais eram, em verdade, estruturas de um único aparelho de poder. Os juízes agiam por delegação dos detentores do poder econômico e político, limitando-se a reproduzir a vontade expressa nas leis.

O advento do período pós-guerras, da concepção do Estado Social, da teoria dos princípios e da Nova Hermenêutica Constitucional evidenciou que os tempos atuais demandam proteção contra os abusos da lei, o arbítrio dos Parlamentos e a falta de efetividade dos comandos constitucionais. A sociedade contemporânea demanda proteção contra a instrumentalização do direito e das leis em favor dos mercados e das minorias abastadas. É neste contexto que se coloca a necessária releitura do dogma da separação de poderes (JORGE NETO, 2008, p. 61). A separação de poderes, nos moldes como preconizada pelo Iluminismo, não é capaz de responder aos anseios do Estado Social. A lei já não é um valor em si. O poder estatal somente se legitima na medida em que, além de assegurar as liberdades, busca fundamentalmente promover a igualdade entre seus súditos. Limitar o poder implica assegurar que o poder estatal esteja sempre a serviço da igualdade e da promoção do bem comum aos cidadãos, por meio de ações positivas (JORGE NETO, 2008, p. 64). Afinal de contas, direitos precisam ser garantidos.

Indispensável destacar, com Andreas Krell (2002, p. 87), que a inconstitucionalidade

\footnotetext{
${ }^{5}$ Sobre a noção de democracia deliberativa, vide Cláudio Pereira de Souza Neto (SOUZA NETO, 2006).
} 
permanente, decorrente da não concretização dos direitos inscritos no Texto Constitucional, conduz inevitavelmente à desestabilização política. $\mathrm{O}$ distanciamento entre os textos constitucionais e a realidade social origina o mais severo grau de crise política, designada por Paulo Bonavides (2007, p. 576) de crise constituinte: nela, ocorre a desmoralização política da sociedade, com padecimento dos direitos fundamentais.

Em suma, a conjugação do modelo de constitucionalismo social com o reconhecimento do caráter normativo e judicialmente sindicável dos preceitos constitucionais - inclusive os mais vagos - alterou substancialmente a relevância da Constituição no sistema jurídico. Alterou-se, de igual, o equilíbrio de poder estatal, com fortalecimento do Judiciário e, sobretudo, das Cortes Constitucionais, não raras vezes em detrimento das escolhas realizadas nas instâncias políticas majoritárias (SOUZA NETO e SARMENTO, 2015, p. 76).

A experiência atual tem demonstrado que as questões públicas mais relevantes quase nunca são resolvidas nas arenas políticas tradicionais. De um lado, o Legislativo, em situações diversas, decide não decidir (opção estratégica), omitindo-se de enfrentar questões eleitoralmente espinhosas (uniões homoafetivas ou liberação do consumo de maconha, por exemplo). A delegação ao Judiciário do poder de decisão, em tais situações, é mais conveniente para os órgãos representativos. A situação evidencia a crise da democracia representativa, não apenas pelos descaminhos havidos no processo eleitoral (especialmente no financiamento de campanhas), mas, sobretudo, porque muitas vezes a deliberação judicial mais se aproxima dos anseios sociais do que aquelas advindas do Legislativo (casos da Lei da Ficha Limpa e da interrupção da gravidez de feto anencefálico, por exemplo).

Avulta, no ponto, o papel contramajoritário do Poder Judiciário (TASSINARI, 2013, p. 34). Indiscutível que o Judiciário precisa, não raras vezes, atuar de forma incisiva, enfrentando a classe política e outros órgãos do poder soberano, tudo para garantir, de forma mais ousada, os direitos dos cidadãos, como assinala Boaventura de Sousa Santos (2009, p. 108-128). O autor refere-se ao protagonismo judicial. Há graus diversos de protagonismo, a depender da posição do país no sistema mundial, do seu nível de desenvolvimento econômico e social, da sua cultura jurídica e dos processos históricos que desencadearam a construção de cada Estado. A precarização de direitos econômicos e sociais, o nível de efetividade de aplicação dos direitos e a (in)existência de estruturas administrativas que ofereçam suporte a essa aplicação também justificam a busca pelo Judiciário. O protagonismo judicial é, pois, resultante da vocação do tempo presente para a jurisdição.

A situação de protagonismo ao qual foi erigido o aparelho judicial do estado não resulta 
de desejo deliberado dos que o integram. É, antes, efeito inesperado da transição para a democracia, sob a circunstância geral - não apenas brasileira - de reestruturação da relação entre Estado e Sociedade. A mantença do Poder Judiciário em posição de neutralidade política faria dele um poder anacrônico. A desneutralização, a emergência do ativismo e a judicialização da política são processos afirmativos verificados universalmente (VIANNA; CARVALHO; MELO e BURGOS, 1997, p. 12, 29 e 31). Na quadra atual, portanto, o juiz foi erigido à condição de guardião das promessas constitucionais (GARAPON, 2004).

\section{ATIVISMO JUDICIAL: UM CONCEITO AMBÍGUO}

A mudança do perfil da atuação judicial, que transportou o juiz (especialmente o brasileiro) para o centro do jogo político, ensejou fosse cunhada a expressão judicialização da política, referida no item anterior. Atribuiu-se ao juiz a responsabilidade, em última análise, pela efetivação do Texto Constitucional. Paulo Bonavides (2007, p. 587), por exemplo, refere a figura do juiz social, consectário derradeiro de uma teoria material da Constituição. Para Bonavides, o juiz social é aquele que, dando plena efetividade ao texto constitucional, contribui para a diminuição das desigualdades sociais, especialmente nos países subdesenvolvidos. Referida noção é tanto mais relevante em país que, como assinala Gustavo Amaral (2010, p. 2), primava pela "insinceridade normativa".

O exercício de referido mister não se faz sem críticas severas. Já se aludiu ao déficit de democracia dos membros do Judiciário e à ausência de coerência e estabilidade nas decisões. Atuação com tais características tem sido alcunhada de ativista. Importa, então, estabelecer distinção entre os conceitos de judicialização da política e de ativismo judicial. A judicialização da política caracteriza-se pelo deslocamento das deliberações de uma sociedade da arena política tradicional (Parlamento) para a esfera judicial. O ativismo judicial corresponde a um modo de interpretação proativa e expansiva, especialmente no suprimento de omissões legislativas que se traduzem, na prática, em óbices para a fruição de direitos.

Na lição de Luís Roberto Barroso (2012, p. 372), a judicialização é um fato, uma circunstância do desenho institucional brasileiro. Já o ativismo corresponde a uma atitude. Diz com a escolha de um modo específico e proativo de interpretar a Constituição, expandindo seu sentido e alcance. Usualmente tem lugar em situações nas quais há retração do Poder Legislativo, que se omite no enfrentamento de determinadas demandas sociais.

Relevante anotar que o termo ativismo judicial tem significado dúbio. No plano 
nacional, a expressão é muitas vezes utilizada em acepção positiva, referindo: (a) decisões judiciais que busquem efetivar direitos fundamentais; (b) decisões judiciais orientadas à garantia da supremacia da Constituição e (c) decisões judiciais fundamentadas em princípios jurídicos, sobretudo em princípios constitucionais (ABBOUD e LUNELLI, 2016, p. 21).

Para a doutrina estadunidense (de onde o termo foi haurido), contudo, o ativismo é apontado como um problema hermenêutico, relacionado com a invasão das preferências ideológicas dos julgadores nas decisões judiciais (ABBOUD e LUNELLI, 2016, p. 21). Em tom de crítica severa, Ronald Dworkin (2007, p. 451) anota que o ativismo é uma forma virulenta de pragmatismo jurídico. Referido posicionamento igualmente encontra eco em doutrina nacional. Para Lênio Streck: "Um juiz ou tribunal pratica ativismo quando decide a partir de argumentos de política, de moral, enfim, quando o direito é substituído pelas convicções pessoais de cada magistrado (ou de um conjunto de magistrados)" (2011, p. 598).

Para a referida corrente de pensamento, portanto, toda manifestação de ativismo judicial é perniciosa para o regime democrático, na medida em que consistiria em degeneração ideológica da atividade interpretativa/aplicativa do Judiciário. A corrente de pensamento por último abordada ignora a origem da expressão e a equivocidade do termo.

Paulo Gustavo Gonet Branco (2013, p. 389) descreve que a expressão ativismo judicial padece de indeterminação semântica. A confusão provavelmente tem relação com a própria origem do termo. A designação judicial activism surgiu em contexto não-técnico. Teria sido cunhada por Arthur Schelsinger Jr. em artigo publicado na Revista Fortune, em 1947. A matéria não se propunha a discutir o papel do Judiciário na sociedade. Descrevia as antipatias recíprocas entre os grupos de juízes que formavam a Suprema Corte Americana de então. Sem preocupação conceitual ou metodológica, os juízes foram divididos em dois grupos, rotulados de "ativistas judiciais" e de "campeões de auto-contenção" (self-restraint).

A ambiguidade do termo tem ensejado, especialmente no plano nacional, entrechoque de visões apaixonadas. Em obra indispensável sobre o tema, Elival da Silva Ramos (2010, p. 129) designa de ativismo o exercício da função jurisdicional para além dos limites impostos pelo ordenamento, é dizer, invadindo a esfera de deliberações públicas antes reservadas ao Legislativo e o Executivo. Trata-se, para aquele autor, de "insidioso caminho", que merece repulsa. Em sentido oposto, o decano do Supremo Tribunal Federal, Ministro Celso de Mello, ao saudar a ascensão do Ministro Gilmar Mendes à Presidência daquela Corte, enalteceu a atuação do STF, designando-a de ativista. Salientou que tratar-se-ia de necessidade institucional, imposição incontornável da necessidade de fazer prevalecer a primazia da 
Constituição da República. Ao assim agir, portanto, o STF estaria apenas cumprindo sua função (BRANCO, 2013, p. 394).

A teoria dos direitos fundamentais prevalente no Brasil, que admite ponderação de princípios constitucionais, de forma a emprestar-lhes máxima efetividade, de um lado, e a possibilidade de realização do controle de constitucionalidade no caso concreto (difuso), de outro, acabam reforçando o papel do julgador que se pretende moderno (ou social, na expressão cunhada por Paulo Bonavides e aqui já referida), qual o de buscar emprestar máxima efetividade ao Texto Constitucional. Na mesma toada, a moderna compreensão de que os dispositivos constitucionais ou legais não passam de texto. Para tornarem-se normas, passam pela interpretação. A norma é extraída do texto pelo intérprete. No exercício de sua atividade, o juiz interpreta o texto constitucional ou legal, para, a partir daí, criar a norma que solucionará o caso concreto. O contexto estimula a criatividade judicial (ambiente decisional frouxo, com cláusulas de conteúdo jurídico indeterminado) e a atuação proativa do julgador, no sentido de emprestar máxima efetividade ao Texto Constitucional, interpretando os textos legislados e deles extraindo a norma do caso concreto. O risco, em tais condições, é o de que o ato de decidir seja contaminado pela ideologia de cada julgador.

De fato, não pode deixar de ser repudiada - e, por isto, tem sido várias vezes designada de ativista, na acepção que mais se aproxima da visão de Ronald Dworkin, já referida - a atuação do juiz que decide conforme suas predisposições políticas, econômicas, religiosas. Nesse sentido, portanto, o ativismo consistiria em degeneração ideológica da atividade interpretativa/aplicativa desenvolvida pelo Judiciário (ABBOUD e LUNELLI, 2016, p. 29). Atuação judicial com referido perfil não necessariamente será vanguardista (recordem-se as notórias resistências de vários julgadores à adequada aplicação da Lei da Violência Doméstica, por exemplo). O que se repudia, então, é o decisionismo, a atuação judicial voluntarista, solipsista, que deliberadamente busca imposição das preferências pessoais do julgador. O cotidiano forense evidencia permanente vilipêndio da regra do art. 93, IX, da Constituição Federal. Assim, apenas uma fundamentação constitucionalmente adequada, em constante diálogo com o momento histórico, legitima a atuação do Poder Judiciário como espaço de deliberações públicas.

A atuação do julgador socialmente responsável, portanto, precisa ser transformadora, na busca da atribuição de maior grau de efetividade possível ao Texto Constitucional. O protagonismo que daí resulta não pode, contudo, servir de justificação para sobreposição dos valores e convicções pessoais de cada julgador (ou de um conjunto deles, no caso de órgãos 
colegiados) às escolhas legitimamente realizadas nos espaços tradicionais da arena política (no Parlamento, sobretudo). Apenas a utilização de adequada fundamentação, que considera o momento histórico em que se dá a atividade de interpretação do texto e construção da norma do caso concreto, é capaz de legitimar atuação judicial protagonista.

Postas tais premissas, resta avançar no objetivo inicialmente proposto. Recorde-se que o que se pretende é realizar estudo de decisões judiciais envolvendo proteção ao meio ambiente, de forma a explicitar se ali há, ou não, ativismo judicial. Para tanto, indispensável conceituar meio ambiente, consideradas suas acepções, tudo de forma a justificar a necessidade de sua proteção.

\section{A PROTEÇÃO AMBIENTAL NO BRSIL: ALGUMAS CONSIDERAÇÕES}

O meio ambiente vem sendo analisado e estudado por várias áreas do conhecimento. A Biologia, a Química, a Física, a Economia, a Sociologia, a Política e também o Direito têm se debruçado sobre o tema. $\mathrm{O}$ assunto é transdisciplinar e tem reflexos nos saberes sociológico e jurídico - aqueles que interessam para os fins do presente trabalho. Tanto que se constata a influência do comportamento humano nos sistemas ecológico e social.

Assiste-se progressiva aceleração das alterações da face da Terra. ${ }^{6} \mathrm{O}$ desequilíbrio ecológico é evidente. Na sociedade moderna, o ambiente passou a ser um recurso explorado pelo homem de forma ilimitada, utilizando-o como um dos fatores do sistema econômico, notadamente focado no pensamento antropocêntrico clássico e utilitarista. $\mathrm{O}$ ser humano explora a natureza, sem perceber que é parte dela. Ao prejudicá-la, afeta a si mesmo. Tais prejuízos são encarados na modernidade como riscos que afetam o planeta e atingem a todos indiscriminadamente.

Para Ulrich Beck (1998, p. 17 e 34), vive-se em uma "sociedade de risco". O termo remete à sociedade atual, onde desafios inicialmente escondidos, por ela própria produzidos, levam à autodestruição e à eliminação de todas as formas de vida no planeta Para Beck, risco

\footnotetext{
6 “O período geológico chamado de Holoceno, que se iniciou há 11.700 anos e continua até o presente, tem sido uma época relativamente estável do ponto de vista climático (Crutzen, 2002). Desde os anos 80, alguns pesquisadores começaram a definir o termo Antropoceno como uma época em que os efeitos da humanidade estariam afetando globalmente nosso planeta. O prêmio Nobel de Química (1995) Paul Crutzen auxiliou na popularização do termo nos anos 2000, através de uma série de publicações discutindo o que seria essa nova era geológica da Terra (Crutzen, 2002) na qual a influência humana se mostra presente em algumas áreas, em parceria com as influências geológicas. A humanidade emerge como uma força significante globalmente, capaz de interferir em processos críticos de nosso planeta, como a composição da atmosfera e outras propriedades"(ARTAXO, 2014, p. 15).
} 
significava ousadia e aventura, parecendo que a busca pelo crescimento seria apenas um desafio. As consequências da superprodução industrial, da globalização e da competição pelo crescimento econômico esbarram nos limites dos recursos naturais, que são finitos ${ }^{7}$, pondo em risco o que ainda resta do meio ambiente saudável.

De outro giro, o meio ambiente não se reduz somente à natureza e aos recursos naturais. As questões ambientais podem envolver relações tanto de direito público, quanto de direito privado. Para os fins do trabalho, importa buscar delimitar o conceito de meio ambiente. José Afonso da Silva (2007, p. 20) descreve o meio ambiente como "a interação do conjunto de elementos naturais, artificiais e culturais que propiciem o desenvolvimento equilibrado da vida em todas as suas formas”. Já Celso Antônio Pacheco Fiorillo (2013, p. 61) defende que meio ambiente possui um conceito jurídico indeterminado, cujo conteúdo é preenchido pelo intérprete/aplicador.

Aqui, adota-se a noção de meio ambiente como o conjunto de fatores de ordem física, química e biológica, material e imaterial que abriga e rege a vida em todas as suas formas (artigo $3^{\circ}$, da Lei $n^{\circ}$. 6.938/81, recepcionado pela CF/88). Prevalece uma ideia muito ampla de fatores que interagem contínua e evolutivamente. Todas as formas de vida são destinatárias da proteção ambiental (não apenas o homem, como seria na visão antropocêntrica) e isto envolve várias dimensões. Interessante analisá-las.

A expressão meio ambiente natural refere-se aos recursos naturais ou físicos como a atmosfera, as águas interiores, superficiais e subterrâneas, os estuários, o mar territorial, o solo, o subsolo os elementos da biosfera, às diversas espécies da fauna e da flora (artigo $3^{\circ}, \mathrm{V}$, da Lei $\mathrm{n}^{\mathrm{o}}$. 6.938/81), ao patrimônio genético e à zona costeira (artigo 225 , II e $\S 4^{\circ}$, da CF/88). A natureza era considerada inesgotável. Transformações nefastas, como a poluição, a chuva ácida, a desertificação, o efeito estufa e o derretimento das geleiras causaram, em todo o mundo, uma verdadeira crise ecológica. Os recursos naturais são essenciais à vida do homem na Terra. Devem, ainda, ser adequados para as presentes e futuras gerações.

\footnotetext{
${ }^{7}$ A medida de consumo de recursos naturais pelo homem em relação à capacidade da Terra para repô-los é entendida pelo conceito de "pegada ecológica" criado por William Rees e Mathis Wackernagel, pesquisadores da universidade canadense de British Columbia, na década de 1990. "Se a capacidade de consumo continuar nesse ritmo, a pegada ecológica (metodologia utilizada para medir as quantidades de terra e água - em termos de hectares globais - gha) subirá, tornando inviável a sobrevivência do homem no planeta. [...] O Relatório Planeta Vivo 2012 demonstrou que a pegada ecológica do Brasil é maior que a média mundial e maior que a de todos os países do grupo BRICS, exceto Rússia (inclui China, Índia e África do Sul). A pegada da humanidade hoje excedeu em 50\% a capacidade de regeneração do planeta. Em outras palavras, para sustentar o padrão de consumo atual, seria necessário 1,5 planeta. A pegada da humanidade dobrou desde 1996. A pegada brasileira é de 2,93 hectares por pessoa contra 2,70 da média global" (SIRVINSKAS, 2015, p. 82-83).
} 
Ambiente artificial, na descrição de Luís Paulo Sirvinskas (2015, p. 759), é aquele construído pelo homem e pode acontecer em áreas rurais e urbanas. Está diretamente relacionado ao conceito de cidade e qualifica algo que se refere a todos os espaços habitáveis (FIORILLO, 2013, p. 63). Na medida em que as cidades vão surgindo, se agrupando e se expandindo, o processo de urbanização passa a ser inevitável. Graves problemas são gerados pelo uso e a ocupação desordenados dos espaços das cidades, comprometendo questões relativas a alimentos, saneamento básico, água, mobilidade urbana, atendimento de saúde e outros. A qualidade de vida das cidades abrange vários aspectos: moradia, transporte, segurança, trabalho, lazer e meio ambiente saudável. Faz-se necessária a efetivação de uma política de desenvolvimento urbano que garanta a função social das cidades sustentáveis e o bem-estar de sua população.

Por meio ambiente do trabalho designa-se o local onde o indivíduo exerce suas atividades laborais, seja no campo ou na cidade. Abrange, inclusive, os espaços utilizados por aqueles que, devido ao avanço das tecnologias modernas, exercem suas atividades na própria moradia. Importa que nesse ambiente sejam considerados os possíveis riscos de exposição a produtos perigosos ou atividades insalubres. Objetiva-se a melhor saúde e a segurança do trabalhador. Para José Afonso da Silva (2007, p. 23), o meio ambiente do trabalho insere-se no artificial e merece tratamento especial.

Bastante abrangente a dimensão do meio ambiente cultural. Édis Milaré (2010, p. 317 318) pontua que a tutela jurídica da proteção ao patrimônio cultural foi iniciada com a Constituição de 1934 e aprimorada nas seguintes. Teve maior abrangência com a Carta de 1988, em seus artigos 215 e 216. Além de albergar bens de valor histórico, artístico, arqueológico e paisagístico, o patrimônio cultural revela a formação, a criação, a identidade, a ação e a memória de diferentes grupos da sociedade. Engloba todos os elementos que constituem a cidadania de um povo.

Inconteste que a quadra atual marca a centralidade da temática ambiental. Debates a tal respeito passam a fazer parte da pauta de encontros de organismos internacionais, representantes de governos e de estados dos países do mundo. Com o agravamento da crise socioambiental mundial, diversos estados começaram a se preocupar com o assunto da degradação ambiental como consequência do crescimento econômico desmedido.

Na época da Conferência das Nações Unidas em Estocolmo $(1972)^{8}$, predominava para

\footnotetext{
${ }^{8}$ Ressalte-se que foi na Conferência de Estocolmo que se firmou o reconhecimento internacional de que "o meio ambiente humano é essencial para o bem-estar do homem e para o gozo dos direitos humanos fundamentais,
} 
um determinado grupo de países, do qual infelizmente o Brasil era líder, o equivocado entendimento de que os recursos naturais seriam infindáveis. Este grupo preconizava a ideia do "crescimento a qualquer custo" e de que, por serem nações subdesenvolvidas ou em desenvolvimento, não deveriam investir na proteção ao meio ambiente (MILARÉ, 2010, p. 66). A partir de Estocolmo, há uma atuação dos Estados no sentido de desenvolver práticas de mitigação dos desequilíbrios ambientais, em razão das relações necessárias de meio ambiente além das fronteiras individuais.

Os movimentos internacionais fortaleceram o surgimento do Direito Ambiental no cenário jurídico internacional. A título de ilustração, as Conferências da Organização das Nações Unidas (ONU) mais famosas em matéria ambiental foram: Estocolmo (1972); Rio-92 (1992); Quioto (1997) - Conferência entre as Partes (COP 3) - que originou o Protocolo de Quioto; Johanesburgo (2002) e a Rio+20 (2012) - (SARLET e FENSTERSEIFER, 2014, p. 154). Consequência dos diversos movimentos internacionais, muitos governos passaram a adotar, em suas legislações, políticas de proteção ao meio ambiente, incorporando-as em suas constituições a partir de meados das décadas de 1970 (BENJAMIN, 2010, p. 80). Pode-se citar que, após a Conferência de Estocolmo, em 1972, países europeus que se libertaram da ditadura vieram a regulamentar o meio ambiente em suas constituições. É o caso da Grécia (1975), de Portugal (1976) e da Espanha (1978) - (BELCHIOR, 2011, p. 60).

No Brasil, a positivação de proteção ao meio ambiente só se deu a partir de 1981, com a promulgação da Política Nacional do Meio Ambiente (Lei no 6.938/81). Com o advento da Constituição de 1988, o meio ambiente ecologicamente equilibrado atingiu o status de direito e dever fundamental. A introdução do tema no Texto Constitucional representou um marco para o Direito Ambiental. De fato, a Constituição Federal de 1988 devotou, pela primeira vez na história constitucional brasileira, um capítulo específico à defesa do meio ambiente. Nela, o meio ambiente ecologicamente equilibrado passou a ser reconhecido como um direito fundamental material, ainda mesmo sem integrar explicitamente o rol inserido no respectivo Título II $^{9}$.

Ao estabelecer que devam ser tidos como tais não apenas aqueles nela expressamente

inclusive o direito à vida". (BIANCHI, 2007, p. 205).

${ }^{9} \mathrm{O}$ catálogo dos direitos fundamentais está estabelecido no Título II da Constituição da República, que trata dos direitos e garantias fundamentais; Capítulo I, que cuida dos direitos e deveres individuais e coletivos. Neste catálogo estão consagrados direitos fundamentais das diversas dimensões. Com relação ao direito ao meio ambiente ecologicamente equilibrado, estabelecido no caput do art. 225, da Constituição Federal, direito de terceira dimensão, este se encontra localizado no texto constitucional, mas fora do título dos direitos fundamentais. 
positivados, mas também aqueles que dela possam ser extraídos por interpretação (regime e princípios por ela adotados), a Constituição de 1988 consagrou a noção aberta de fundamentalidade dos direitos (SARLET, 2009, p. 104). O rol ainda é passível de ampliação decorrente de tratados internacionais dos quais a República Federativa do Brasil seja parte (art. $\left.5^{\circ}, \S 2^{\circ}\right)$.

A Constituição de 1988 assegura a todos o direito ao meio ambiente ecologicamente equilibrado (art. 225). Trata-se de bem de uso comum do povo e essencial à sadia qualidade de vida. De dita regra constitucional resulta imposição ao Poder Público e à coletividade o dever de defesa ${ }^{10}$ e preservação do meio ambiente, seja para a geração presente, seja para as futuras.

A qualidade de vida é decorrência da qualidade ambiental: visa garantir uma “existência humana digna e saudável” (SARLET e FENSTERSEIFER, 2010, p. 14), daí estabelecer-se existir direito de todos ao bem-estar e à saúde ambiental. O direito a um meio ambiente ecologicamente equilibrado é corolário do próprio direito à vida, indispensável a uma condição de sobrevivência digna (CAVALCANTE e MENDES, 2008, p. 29-39).

Verifica-se uma nova conformação do modelo normativo do princípio da dignidade da pessoa humana. Valores ecológicos são colocados no "coração" do Direito brasileiro e passam a influenciar todos os ramos jurídicos, chegando até a limitar outros direitos (SARLET e FENSTERSEIFER, 2014, p. 241).

Incumbe, em tais condições, realizar a última etapa do presente trabalho, qual seja, o estudo de alguns casos em que o Judiciário atuou na proteção do meio ambiente. Cumpre, na análise por ser realizada, buscar evidenciar elementos que permitam afirmar se, em cada um dos casos examinados, o Judiciário: (1) agiu de forma a dar plena efetividade às normas constitucionais, assegurando efetiva proteção ao meio ambiente (atuação protagonista, nos moldes da abordagem realizada nos tópicos anteriores); (2) agiu transcendendo os limites das regras constitucionais, sobrepondo as vontades ideológicas do juiz ou tribunal às escolhas realizadas na arena política tradicional e materializadas por meio do Texto Constitucional (atuação ativista) ou (3) omitiu-se na proteção constitucionalmente imposta e, em decorrência, acabou por legitimar agressões ao meio ambiente.

${ }^{10}$ A respeito da noção de proteção ao meio ambiente como dever fundamental, vide Germana Belchior (2011, p. 11-12). 


\section{ESTUDO DE CASOS}

A proteção do meio ambiente é um avanço na ordem jurídica nacional. Não é raro, contudo, que a proteção seja negligenciada ou realizada de forma incompleta. Teoria e prática nem sempre caminham juntas. A doutrina dedica-se às questões ambientais, atenta à complexidade da realidade que se apresenta. A eficácia social das normas jurídicas, porém, depende da atuação dos aplicadores do Direito Ambiental, incluídos gestores públicos e magistrados. Estes últimos, especialmente os membros das Cortes Superiores, devem confirmar as expectativas de proteção.

Com atenção na discussão aqui desenvolvida, foram selecionados, para exame, precedentes judiciais de diferentes tribunais. Foram selecionados casos em que o ponto central da controvérsia em discussão diz com a proteção do meio ambiente, em diferentes acepções. A partir do exame dos casos escolhidos, evidencia-se que os tribunais nacionais, especialmente o STF, passaram a adotar, na temática ambiental, firme posição protagonista, na pretensão de máxima efetividade constitucional. O caminhar nem sempre é firme. Há decisões que podem ser designadas de ativistas e que, por isto, merecem repúdio.

\subsection{STF-ADPF $n^{o}$. 101: Importação de pneus usados ${ }^{11}$}

Paradigmático o posicionamento adotado pelo STF no julgamento da Ação de Descumprimento de Preceito Fundamental referida no subtítulo.

Acordos firmados pelo Brasil no âmbito do Mercosul autorizavam a importação de remoldados (pneus recapados) oriundos dos países do bloco. A autorização restringia-se ao produto final, não às carcaças. Decisões judiciais diversas, oriundas de juízos ordinários, passaram a autorizar que também fossem importados pneus remoldados originários de países da Comunidade Europeia. Tais decisões, sustentou-se, ignoravam regras infralegais (portarias do Departamento de Comércio Exterior - Decex e da Secretaria de Comércio Exterior - Secex, resoluções do Conselho Nacional do Meio Ambiente - Conama e decretos federais) que expressamente vedam a importação de bens de consumo usados (especialmente pneus). Da mesma forma, ignoravam o teor da Convenção da Basileia, em vigor desde 5/5/1992 e à qual o Brasil aderiu (texto aprovado pelo Decreto $n^{\circ} .875$, de 19.7.93). Ali, estabeleceu-se que a maneira mais eficaz de proteger a saúde humana e o ambiente dos perigos causados pelos

\footnotetext{
${ }^{11}$ Informações colhidas por meio do site www.stf.jus.br.
} 
resíduos perigosos é reduzir a sua produção ao mínimo, sendo legítimo o direito de qualquer estado soberano proibir a entrada de resíduos perigosos em seu território.

Com o objetivo de desconstituir tais decisões, a Presidência da República. Levou a questão ao STF.

Em alentado voto, que findou por prevalecer, a Ministra Carmen Lúcia reafirma o compromisso do STF em proteger o meio ambiente ${ }^{12}$, mesmo em detrimento da atividade econômica. Destaca questões técnicas, relacionadas com a eliminação (queima/destruição) das carcaças de pneus, reconhecidas pela Convenção de Estocolmo (realizada em 1972, mas somente assinada pelo Brasil e promulgada pelo Decreto $n^{\circ}$. 5.472, de 20/06/2005).

Aponta, com veemência, que é vedado ao Poder Público ser insuficiente ou imprevidente em suas ações e decisões que tenham o objetivo de dotar de proteção os direitos fundamentais, pena de a inoperância ou a ausência de ações afetarem o núcleo central desses direitos. Ao cabo, conclui pela constitucionalidade de interpretação que proíba a importação de pneus usados de qualquer espécie. Na esteira do voto da Relatora, portanto, o STF agiu de forma a dar máxima efetividade ao Texto Constitucional, assegurando proteção ao meio ambiente.

\subsection{STF-ADI $n^{o}$. 1.856: Lei fluminense que permitia rinhas de galo ${ }^{13}$}

No julgamento da Ação Direta de Inconstitucionalidade em referência, o STF enfrentou a alegação de incompatibilidade da Lei Estadual nº 2.895/98, do Rio de Janeiro, com o Texto Constitucional. Referido diploma legal legitimava a realização de exposição e competições de aves de combate, institucionalizando a prática da crueldade.

No voto que prevaleceu, da lavra do Min. Celso de Mello, restou evidenciado que a promoção de brigas de galos, para além de caracterizar prática tipificada como crime, afronta à Constituição Federal, que veda a submissão de animais a atos de crueldade. Com expressa alusão à chamada "farra do boi" e ao que restou decidido no Recurso Extraordinário no . 153.351/SC, afirmou-se que a alegação de que a realização de rinhas de galo constituiria inocente manifestação cultural, de caráter folclórico, não poderia servir de justificativa para a perpetração da crueldade.

A referida Lei Estadual foi, portanto, reputada inconstitucional. A decisão foi tomada

\footnotetext{
${ }^{12} \mathrm{O}$ voto refere expressamente o precedente da lavra do Ministro Celso de Melo, exarado na Medida Cautelar na Ação Direta de Inconstitucionalidade n. 3.540, onde restou afirmado o compromisso do STF na proteção do meio ambiente, em estrita observância à regra do art. 225 da Constituição Federal de 1988.

${ }^{13}$ Informações colhidas por meio do site www.stf.jus.br.
} 
por unanimidade, ainda que tenha havido divergência de alguns dos julgadores quanto à fundamentação do voto (o Min. Marco Aurélio, por exemplo, declarou a inconstitucionalidade formal, isto porquanto já haveria Lei Federal vedando a prática que a Lei estadual tentou legitimar). Sob o ponto de vista da discussão aqui proposta, é relevante perceber que o STF, ponderando direitos fundamentais - proteção ao meio ambiente cultural e proteção ao meio ambiente natural, aqui entendido como máxima proteção à fauna -, fez prevalecer o último.

4.3 STF-ADI $n^{o}$. 4.983: Lei cearense que regulamenta a vaquejada como prática esportiva e cultural do Estado ${ }^{14}$

No segundo semestre de 2016, foi julgada pelo STF a Ação Direta de Inconstitucionalidade $\mathrm{n}^{\circ}$. 4.983. Por meio dela, pugnou o Procurador Geral da República pela declaração da inconstitucionalidade da Lei Estadual cearense $\mathrm{n}^{\circ}$. 15.299/2013, que regulamentava a realização da vaquejada.

Os argumentos que fundaram o ajuizamento da mencionada ADI foram substancialmente os mesmos utilizados na ADI $n^{\circ}$. 1.856, referida no item pretérito: foram contrapostos a proteção ao meio ambiente natural (proteção da fauna) e a proteção às manifestações culturais.

Curioso perceber que, naquele primeiro caso, a decisão foi tomada por unanimidade de votos, tal qual restou anotado. No caso da lei cearense, contudo, a votação foi apertada, restando vencidos os Ministros Edson Fachin, Gilmar Mendes, Teori Zavascki, Luiz Fux e Dias Tóffoli.

Manteve-se, portanto, proteção do meio ambiente (fauna), ainda que os votos vencidos pareçam apontar retrocesso em relação ao entendimento consolidado no julgamento que envolveu a realização de rinha de galo.

4.4 TRF1 - Embargos Infringentes na Apelação Cível $n^{o}$. 2000.01.00.064228-04/GO: Pretensão de construção da sede da Procuradoria da República em Goiânia em área de proteção ambiental $^{15}$

Trata-se de Ação Civil Pública movida por Associação dos Moradores do Setor Sul em face da União e do Município de Goiânia/Go. Por meio dela, objetivou-se suspender o edital

\footnotetext{
${ }^{14}$ Informações colhidas por meio do site www.stf.jus.br.

15 Informações colhidas da Revista do Tribunal Regional Federal da 1. Região. V.1, n.1. Out./dez. 1989. Brasília: TRF 1. Região, 1989, p. 71-88.
} 
de licitação para contratação de empresa que seria incumbida da construção de edifício destinado à nova sede da Procuradoria da República naquele Estado. O ponto central da questão diz com o fato de que o local escolhido para a construção estaria localizado em zona de proteção ambiental. Sua efetivação poria em risco a preservação do Córrego dos Buritis. A pretensão foi rejeitada em primeiro grau de jurisdição e reformada no Tribunal Regional Federal da $1^{\text {a }}$ Região, em sede de Apelação. Da decisão proferida no Recurso de Apelação, foram interpostos os Embargos Infringentes sob apreciação.

No respectivo julgamento, manteve-se a posição firmada quando do destrame da Apelação. Afirmou-se, então, que o interesse de dotar a Procuradoria da República de sede adequada ao exercício de suas funções é secundário em relação ao da preservação do Córrego dos Buritis, cuja nascente é insubstituível. Acrescentou-se que a existência de outras construções na área, levadas a efeito antes de implementado o zoneamento ambiental, não poderia servir de justificação para construção de mais uma obra, mormente a sede da Procuradoria da República, seja porquanto o prédio projetado teria cerca de seis mil toneladas, seja, especialmente, porquanto se inclui entre as atribuições do Ministério Público exatamente a defesa do meio ambiente.

Houve, destarte, atuação protagonista da Corte que, a pretexto de emprestar máxima efetividade ao Texto Constitucional, assegurou proteção ao meio ambiente. Do corpo do acórdão, extrai-se que o Relator originalmente designado, Des. Federal Daniel Paes Ribeiro, utilizou como razão de decidir o argumento de que o Ministério Público Federal, como instituição destinada a velar pela correta aplicação da lei e a proteger o meio ambiente, jamais defenderia a construção de sua sede em área de preservação ambiental. O argumento é vigorosamente repudiado pelo Des. Federal João Batista Moreira, que expressamente afirma que tal não passa de argumento de autoridade. Admiti-lo importaria em dizer que o Ministério Público Federal não erra - falácia evidente.

Destaque-se a diferença de posturas: o primeiro julgador invoca argumento metajurídico (o de que o Ministério Público Federal, por sua atribuição institucional, não atuaria em desfavor do meio ambiente), sobrepondo convicção/valor pessoal (crença na correção da atuação do Ministério Público Federal) à vontade constitucional. Atitude ativista, pois. O segundo recoloca a Constituição Federal no centro da discussão, assumindo atitude que, no sentido aqui construído, pode ser designada de protagonista. 


\section{CONSIDERAÇÕES FINAIS}

A quadra atual marca alteração do equilibro do poder estatal. A conjugação do modelo de constitucionalismo social com o reconhecimento do caráter normativo e judicialmente sindicável dos preceitos constitucionais - inclusive os mais vagos - alterou substancialmente a relevância da Constituição no sistema jurídico. O Poder Judiciário, em tal contexto, é conduzido ao epicentro do jogo político.

Enseja, de outra parte, a construção e a contraposição de conceitos muitas vezes equívocos. Para os fins perseguidos no presente trabalho (discussão em derredor da atuação judicial em demandas que envolvem a proteção ao meio ambiente, em seus diferentes matizes), designou-se por judicialização da política o deslocamento das deliberações de uma sociedade da arena política tradicional (Parlamento) para a esfera judicial. Tratar-se-ia de circunstância resultante do desenho institucional brasileiro.

Evidenciou-se, a seguir, que a expressão ativismo judicial, mais que qualquer outra, possui caráter dúbio. Parte da doutrina sustenta que corresponde a um modo de interpretação proativa e expansiva, especialmente no suprimento de omissões legislativas que se traduzem, na prática, em óbices para a fruição de direitos. Corresponderia a uma atitude, vale dizer, à escolha de um modo específico e proativo de interpretar a Constituição, expandindo seu sentido e alcance. Em outra toada, há os que repudiam o ativismo, que se traduziria em forma virulenta de pragmatismo jurídico. Agir de forma ativista, em tal contexto, importaria em ignorar as disposições constitucionais, sobrepondo convicções pessoais àquelas que resultam da arena política tradicional (Parlamento). Logo, sustentam, toda manifestação de ativismo judicial seria perniciosa ao regime democrático, na medida em que consistiria em degeneração ideológica da atividade interpretativa/aplicativa do Judiciário.

Propôs-se superação da dicotomia em prol de uma atuação judicial transformadora da realidade. A atuação do julgador socialmente responsável, portanto, precisa perseguir a atribuição do maior grau de efetividade possível ao Texto Constitucional. Adotou-se, então, a noção de protagonismo judicial, no sentido construído por Boaventura de Sousa Santos. Reforce-se o ponto central: o protagonismo que daí resulta não pode servir de justificação para sobreposição dos valores e convicções pessoais de cada julgador (ou de um conjunto deles, no caso de órgãos colegiados) às escolhas legitimamente realizadas nos espaços tradicionais da arena política (no Parlamento, sobretudo). Apenas uma fundamentação constitucionalmente adequada, em constante diálogo com o momento histórico, legitima a atuação do Poder 
Judiciário como espaço de deliberações públicas.

A questão é sobremodo relevante quando se enfrenta a temática ambiental. De fato, a sociedade contemporânea vive em enorme complexidade. A multiplicidade de riscos, os conflitos e demandas que daí resultam não são passíveis de soluções simples, resultantes de mera aplicação de normas constitucionais, legais e/ou regulamentares, por processo de subsunção.

Diante das premissas antes delineadas, procedeu-se estudo de casos. A partir do exame das razões de decidir expostas em cada uma das situações analisadas, buscou-se demonstrar que os tribunais brasileiros paulatinamente evoluem em sua atuação, na perspectiva de emprestar máxima efetividade ao Texto Constitucional.

\section{REFERÊNCIAS BIBLIOGRÁFICAS}

ABBOUD, George; LUNELLI, Guilherme. Ativismo judicial e instrumentalidade do processo: diálogos entre discricionariedade e democracia. Revista de Processo. v. 242. São Paulo: RT, 2016.

AMARAL, Gustavo. Direito, escassez \& escolha: critérios jurídicos para lidar com a escassez de recursos e as decisões trágicas. 2. ed. Rio de Janeiro; Editora Lumen Juris, 2010.

ARTAXO, Paulo. Uma nova era geológica em nosso planeta: o antropoceno? Revista USP, São Paulo, n. 103, 2014, p. $15 . \quad$ Disponível em: http://www.revistas.usp.br/revusp/article/viewFile/99279/97695. Acesso em 18.jul.2016.

BARCELLOS, Ana Paula de. Ponderação, racionalidade e atividade jurisdicional. Rio de Janeiro: Renovar, 2005.

BARROSO, Luís Roberto. O controle de constitucionalidade no direito brasileiro. 6. ed. rev. e atual. São Paulo: Saraiva, 2012.

BIANCHI, Patrícia Nunes Lima. A (in)eficácia do direito ao meio ambiente ecologicamente equilibrado no Brasil. Tese apresentada como requisito ao título de doutora da Universidade Federal de Santa Catarina. Florianópolis, 2007.

BECK, Ulrich. La sociedade del riesgo: hacia una nueva modernidad. Trad. José Navarro, Daniel Jiménez, Maria Rosa Borrás. Barcelona: Ed. Paidós Ibérica, 1998.

BELCHIOR, Germana Parente Neiva. Hermenêutica jurídica ambiental. São Paulo: Saraiva, 2011.

BENJAMIM, Antônio Herman. Constitucionalização do ambiente e ecologização da constituição brasileira. In: CANOTILHO, José Joaquim Gomes; LEITE, José Rubens Morato (Orgs.). Direito constitucional ambiental brasileiro. 3. ed. São Paulo: Saraiva, 2010.

BONAVIDES, Paulo. Curso de direito constitucional. 21. ed. São Paulo: Malheiros, 2007. 
BRANCO, Paulo Gustavo Gonet. Em busca de um conceito fugidio: o ativismo judicial. In FELLET, André Luiz Fernandes; PAULA, Daniel Giotti e NOVELINO, Marcelo (Org.). As novas faces do ativismo judicial. 2. tiragem. Salvador: Juspodivm, 2013.

CAVALCANTE, Denise Lucena; MENDES, Ana Stela Vieira. Constituição, direito tributário e meio ambiente. Revista Nomos. v. 28.2. Fortaleza: Universidade Federal do Ceará, 2008.

DWORKIN, Ronald. O império do direito. Trad. Jefferson Luiz Camargo. 2. ed. São Paulo: Martins Fontes, 2007.

FIORILLO, Celso Antônio Pacheco. Curso de direito ambiental brasileiro. 14. ed. São Paulo: Saraiva, 2013.

GARAPON, Antoine. O Juiz e a democracia: o guardião de promessas. 2. ed. Rio de Janeiro: Renavan, 2004.

JORGE NETO, Nagibe de Melo. O controle jurisdicional das políticas públicas: concretizando a democracia e os direitos fundamentais. Salvador: Editora Juspodivm, 2008.

KRELL, Andreas J. Direitos sociais e controle judicial no Brasil e na Alemanha. Porto Alegre: Sérgio Antônio Fabris Editor, 2002.

MILARÉ, Édis. Direito do ambiente: a gestão ambiental em foco: doutrina, jurisprudência, glossário. 7. ed. São Paulo: Revista dos Tribunais, 2011.

PICARDI, Nicola. Jurisdição e processo. Organização e revisão técnica de tradução de Carlos Alberto Álvaro de Oliveira. Rio de Janeiro: Forense, 2008.

RAMOS, Elival da Silva. Ativismo judicial: parâmetros dogmáticos. São Paulo: Saraiva, 2010.

SANTOS, Boaventura de Sousa. Sociología jurídica crítica: para un nuevo sentido común en el derecho. Madri: Editorial Trotta/Ilsa, 2009.

Para uma revolução democrática da justiça. São Paulo: Editora Cortez, 2007.

SARLET, Ingo Wolfgang. A eficácia dos direitos fundamentais. 9. ed. Porto Alegre: Livraria do advogado, 2009.

SARLET, Ingo Wolfgang; FENSTERSEIFER, Tiago. Estado socioambiental e mínimo existencial (ecológico?): algumas aproximações. In: KRELL, Andreas J.; SARLET, Ingo Wolfgang (Org.). Estado socioambiental e direitos fundamentais. Porto Alegre: Livraria do Advogado Editora, 2010.

SARLET, Ingo Wolfgang; FENSTERSEIFER, Tiago. Direito ambiental: introdução, fundamentos e teoria geral. São Paulo: Saraiva, 2014.

SILVA, José Afonso da. Direito ambiental constitucional. 6. ed. São Paulo: Malheiros, 2007.

SILVA, Virgílio Afonso da. Direitos fundamentais: conteúdo essencial, restrições e eficácia. São Paulo: Malheiros, 2009. 
O Judiciário e as políticas públicas: entre transformação social e obstáculo à realização de direitos sociais. In: SOUZA NETO, Cláudio Pereira de e SARMENTO, Daniel (Org.). Direitos sociais: fundamentos, judicialização e direitos sociais em espécie. Rio de Janeiro: Lumen Juris, 2008.

SIRVINSKAS, Luís Paulo. Manual de direito ambiental. 13. ed. São Paulo: Saraiva, 2015.

SOUZA NETO, Cláudio Pereira de. Teoria constitucional e democracia deliberativa: um estudo sobre o papel do direito na garantia das condições para a cooperação na deliberação democrática. Rio Janeiro: Renovar, 2006.

SOUZA NETO, Cláudio Pereira de; SARMENTO, Daniel. Controle de constitucionalidade e democracia: algumas teorias e parâmetros de ativismo. In: SARMENTO, Daniel (Coord.). Jurisdição constitucional e política. Rio de Janeiro: Gen/Forense, 2015.

STRECK, Lênio Luiz. Verdade e consenso: constituição, hermenêutica e teorias discursivas. 4. ed. São Paulo: Saraiva, 2011.

TASSINARI, Clarissa. Jurisdição e ativismo judicial: limites da atuação do judiciário. Porto Alegre: Livraria do Advogado, 2013.

VIANNA, Luiz Werneck; CARVALHO, Maria Alice Rezende; MELO, Manuel Palácios Cunha e BURGOS, Marcelo Baumann. Corpo e alma da magistratura brasileira. 3. ed. Rio de Janeiro: Revan, 1997. 